\title{
LAND TENURE, MIGRATION, AND DEVELOPMENT A Comparative Case Study
}

\author{
Alisa Garni \\ Kansas State University
}

\begin{abstract}
Comparative analysis of two Salvadoran towns with similar patterns of international migration but different historical land-tenure patterns reveals the emergence of radically different development strategies. Whereas in one case, mostly landed households with a history of farming commercially have been selling land and abandoning agriculture, in the other case, previously landless households whose members worked as sharecroppers before the onset of migration have been acquiring land and farming as much as possible. The opposite processes at work in these two cases raise important theoretical questions for both migration and development studies. Using ethnographic, census, and historical data, I examine how and why land ownership, under particular historical circumstances, conditions the impact of migration on development.
\end{abstract}

Extensive poverty in Central America is linked historically to landlessness among the majority of the region's population (Ripton 2006; Dunkerley 1988; Bulmer-Thomas 1987; World Bank 2007). In the nineteenth and twentieth centuries, oligarchs institutionalized inequality in ownership of productive farmland, access to which would have enabled many Central Americans to incorporate themselves into their national economies. Instead, states constructed agro-export economies and supported the expansion of large estates through the 1970s (Ripton 2006; Dunkerley 1988; Paige 1997). This entailed expelling more and more peasants from the arable land to develop large coffee, cotton, banana, and sugar farms on which landowners managed production for export (Dunkerley 1988). Even today, as Central American leaders deemphasize the agro-export sector to instead experiment with maquiladora-based economies, financed in part by growing migrant remittances (Hausman and Rodrik 2005; Gammage 2006), scholars identify access to arable land as a significant means of buffering families against the effects of all-too-frequent labor market crises (Conning, Olinto, and Trigueros 2001). Central Americans who have at least some access to arable land have been better able to diversify their economic activities to ensure a nominal income or subsistence, whereas those who have remained landless suffer the greatest indices of poverty (World Bank 2007).

In contrast to Mexico, where early twentieth-century revolution stimulated

The author would like to thank L. Frank Weyher, Adrian Favell, César Ayala, Edward Telles, Rubén Hernández León, Dana Britton, László Kulscár, Erynn Casanova, participants in the UCLA International Migration Workshop, and the three anonymous LARR reviewers for helpful comments on previous drafts of this article. The Latin American Studies Program at UCLA and the Mellon Foundation provided financial support for the research. 


\section{Latin American Research Review}

land reforms resulting in the redistribution of more than 50 percent of the country's arable land (Kay 1995), land reform in Central America has been modest and late. Several scholars hold delayed and incomplete land reforms responsible for thwarting development in Central America (Kay 2002; Dunkerley 1988; Ripton 2006; Paige 1997). By contrast, state-led land reform and industrialization in Taiwan and South Korea stimulated greater production of agricultural surplus that was used to feed the urban proletariat inexpensively, thus enabling domestic industrial bourgeoisies to launch new industry locally (Kay 2002; Amsden 1979, 1994). Greater productivity in agriculture also created an internal market for urban industrial goods, as well as a platform for innovation under appropriate macroeconomic management (Wade 1993; Kay 2002, 2006; Amsden 1979, 1990, 2001). Wages in both sectors rose. Central American countries have largely failed to follow this trajectory.

Instead, failed development in Central America has played an important role in stimulating mass migration. Vast inequities in land distribution unleashed peasant uprisings that resulted in civil and revolutionary war across the isthmus from the late 1960s to the 1990s. Hundreds of thousands of Central Americans fled poverty and sociopolitical violence, with more than 80 percent destined for the United States. However, rather than subsiding with the conclusion of these wars, Central American migration persists. El Salvador, Guatemala, Nicaragua, and Honduras are today among the largest and fastest-growing source countries for migration to the United States (US Citizenship and Immigration Services [USCIS] 2009).

El Salvador's significant migratory history and internal variation make it an ideal candidate for studying how the explosion in migration during recent decades bears on actors' efforts to generate development across different local contexts. ${ }^{1}$ During the past twelve years, El Salvador has ranked among the top ten global source countries for unauthorized migrants to the United States: from the year 2000 through 2006, it ranked second, behind Mexico (USCIS 2009). This is particularly remarkable given that Mexico's population of 104 million is nearly fifteen times the size of El Salvador's population of 7 million. From 2004 through 2006, moreover, Salvadorans ranked eighth on the list of source countries for US legal permanent resident flows-five ranks below China and three below Indiaand twelfth for naturalizations during the same time period (USCIS 2009). Nineteen percent of El Salvador's population currently lives abroad, and 22 percent of households in El Salvador receive remittances. ${ }^{2}$ Annual national remittance receipts amount to approximately $\$ 2$ billion, or the equivalent of more than 16 percent of El Salvador's gross domestic product. From 1978 to 2004, the main source of El Salvador's foreign exchange shifted from agro-exports to migrant remittances (Hecht et al. 2006; UN Development Program [UNDP] 2005). At national and household levels, migration affects how Salvadorans use land, manage their assets, and plan futures in El Salvador.

1. Development here refers to the ability of a society to organize its production and distribution of goods and services to maximize the welfare of as many people as possible (Block 1990).

2. However, whereas in some municipalities nearly 75 percent of households engage in migration, in others fewer than 10 percent do (Andrade-Eekhoff 2003; UNDP 2005). 
At the same time, migration occurs across communities with highly variable land-tenure patterns. In some municipalities, few households historically owned their own land, whereas in others, the majority did (Lardé y Larín 2000; Ripton 2006). How do preexisting land-tenure patterns affect the development strategies that local households in high-migration communities pursue?

\section{LAND TENURE, MIGRATION, AND DEVELOPMENT: MAKING CONNECTIONS}

The nature of the relationship between migration and development has long divided scholars. Some scholars draw on modernization theory and argue that development stimulates migration by disrupting peasants' farming communities (Massey 1988; Durand and Massey 1992; Taylor et al. 1996). This migration, in turn, enables money and ideas to flow from more advanced developing countries to less developed ones, and itself becomes a force for development (Massey 1988, 282, 398; Sana and Massey 2005; Levitt and Nyberg-Sørensen 2004). However, once enough jobs are created through urbanization and industrialization, synonymous with development in this view, pressures to migrate will weaken (Massey 1988). In sharp contrast to this view, another set of scholars draws on dependency theories of development to argue that the reverse is true (e.g., Binford 2003; Weist 1984; Reichert 1981). Lack of employment, poor infrastructure, and poor-quality public services stimulate migration, which depletes sending communities of young and able workers, which in turn dampens development prospects. In this view, underdevelopment begets migration and further underdevelopment. Because several scholars have already documented the debate between so-called optimists and pessimists on the question of migration's developmental impact per se (most recently, see Haas 2010), I focus on the extent to which those engaging in this debate address the issue of land tenure more specifically. I then turn briefly to scholarship that suggests how state policy may affect the relationship between land tenure, migration, and development in El Salvador.

From a modernization perspective, Massey $(1988,391-393)$ argues that capital investment and land consolidation are necessary to modernize agriculture and promote development. By the same token, these processes are labor saving rather than labor generating. Modernization of agriculture thus stimulates international migration among displaced peasant farmers, at least until cheap foodstuffs produced through modern agriculture create enough domestic industry to absorb displaced rural workers (Massey 1988; Durand and Massey 1992). Further, rural households receiving remittances are likely to expand the modernization of agriculture by acquiring larger landholdings and investing in new labor-saving technologies, thus perpetuating migration (Durand and Massey 1992, 18-19, 26; see also Massey et al. 1987; Massey 1988, 282, 398; Sana and Massey 2005). Although her work addresses the effects of land tenure on migration and not the effects of land tenure on development, Van Wey (2005) similarly found that members of households with large amounts of land (far above average) are likely to migrate in order to secure capital for investment in acquiring more land and improving production (see also Findley 1987). Although members of landless households also migrate to purchase land, they are less likely to continue to migrate to pur- 


\section{Latin American Research Review}

chase more land once their household has acquired some, even small amounts (in Mexico, an average of 1.6 hectares, or about 4 acres, is sufficient to provide employment and deter migration) (Van Wey 2005, 163). ${ }^{3}$ This means that households lacking land become less likely to participate in migration after acquiring even very small holdings, which tend to provide adequate employment, whereas large landowners may continue migrating to acquire yet more land and capital. ${ }^{4}$ According to these views, land consolidation and migration are likely to promote greater investments in agriculture and/or further migration to cities or other countries. For Massey $(1988,405)$, "the interrelated processes of economic growth, rural-urban migration, and emigration transform a country from an agrarian peasant society to a modern industrial economy."

Scholars extending Massey's early work on the relationship between migration and development examine how migrant remittances affect small-business development more generally. Various scholars (Taylor 1992, 2006; Taylor et al. 1996; Durand, Parrado, and Massey 1996; Woodruff and Zenteno 2006; Massey and Parrado 1994, 1998; Adelman, Taylor, and Vogel 1988) calculated individuals' propensities to invest remittances in any kind of business. ${ }^{5}$ They then estimated a theoretical multiplier effect or how remitted income from the United States may affect output across different sectors in Mexico (Durand, Parrado, and Massey 1996). The authors argue that increased remitting raises household income and thus eases consumers' spending constraints, such that demand for domestic goods rises proportionately. In these studies, however, the issue of whether goods produced to meet increased demand are in fact produced domestically is unresolved, as is the problem of who has the capital necessary to successfully launch businesses designed to meet such demand (Kearney 1986; Kay 2002, 462; Alejandre Arroyo, de León Arias, and Valenzuela Varela 1990).

As my results show, land assets may significantly affect whether remittances will enable people to launch sustainable retail or service businesses, as remittances themselves may provide insufficient capital for purchasing large inventories, securing credit, or expanding services or production. By taking into account how preexisting land-tenure patterns condition the types of development strategies that residents of high-migration communities (with similar amenities) pursue, we enhance our understanding of why some communities create more

3. In a related study, Garip (2010) found that migration deprived wealthier families of needed laborers while enabling poorer families either to use remittances to acquire assets or to avoid having to feed additional people (who would have migrated). Migration, in her view, thus has a neutral impact on development.

4. Durand and Massey (1992); Winters, de Janvry, and Sadoulet (2001); and Massey and colleagues (1987) have found that a positive relationship exists between land tenure and migration, although social networks significantly affect this relationship. As members of households migrate to buy land, they also establish social networks that facilitate ongoing migration. Over time, households that have bought land and established social networks are more likely to migrate. Migration thus enables households to buy land, where it is available, but it is the existence of social networks, rather than land ownership, that stimulates ongoing migration (Durand, Durand, and Massey; Massey et al. 1987).

5. These scholars also draw largely on the theory of new economics of labor migration, which holds that households in developing countries migrate to overcome local market failures and constraints. Remittances thus come to serve as a form of capital for productive local investment. 
nonagricultural than agricultural enterprises and vice versa, and whether small businesses in fact promote additional forms of local productivity.

Roberts's (1982) work reveals that while higher farm incomes and greater local needs for monetary sources of income compel more families to invest in risky international migration to generate money for investment, local agricultural conditions largely determine the outcome of such investments. Where high-quality soil, ideal climates, and easy access to urban markets prevail, agricultural investments are more likely to generate higher farm incomes. By contrast, where soil quality is low and communities are isolated, farmers are less likely to be able to produce high-value crops and earn high incomes, even while investing in improving production (for variants on this argument, see Rahman 2000; Stockdale 2004). In addition, Roberts finds that off-farm labor is not simply a substitute for agriculture but rather an essential component that attracts revenue and opportunities to expand production. On the basis of farming families' income levels and the extent to which their production is monetized, they will decide whether to undertake the risk of sending someone abroad versus allocating their labor to local nonagricultural labor markets, provided that such markets exist.

In sharp contrast to scholarship driven by the modernization theory of development, other works suggest instead that more equitable land distribution patterns are more likely to generate development, as in Southeast Asia, than land concentration, as in much of Latin America (Pelupessy 2000; Kay 2002; Thiesenhusen 1995; Kay 2002, 2006; Amsden 1979, 1990; de Janvry 1981). According to this scholarship, landowners with large and concentrated holdings are likely to purchase new inputs to expand production (unless labor is so inexpensive as to make incorporating labor-saving technologies unattractive), but they will invest less overall than if larger numbers of medium-size farmers were to invest in improving production. With more people farming commercially and adopting new technologies-from basic inputs such as pesticides and fertilizer to large machinery-the demand for new technologies grows faster than it would with a more limited number of people farming profitably (Kay 2002). Further, several scholars have found that as both the industrial and the agricultural sectors adopt more new technologies that require greater skill to operate, wages across sectors rise, thus enabling workers in both industry and agriculture to buy more, and higher-quality, goods from one another (Amsden 1979, 1990, 1994; Kay 2002, 2006; de Janvry 1981; World Bank 2007). In this view, growth in agriculture and industry are mutually complementary, stemming from land reforms that create greater equity, and therefore productivity, in agriculture. In addition, these and other scholars find that landless and land-poor households suffer the highest indices of poverty and are least likely to create off-farm employment, thus limiting the economic diversification necessary for development (World Bank 2007). In this view, land concentration and, by extension, land scarcity threaten development. However, much of this work has neglected the role of migration in development.

Somewhat consistent with the view that equitable land distribution is more likely to facilitate development than concentration is work by migration scholars who draw, to varying degrees, on dependency theories of development. As noted above, these scholars generally argue that migration is both a symptom of under- 


\section{Latin American Research Review}

development and a cause of further underdevelopment. Applied to land tenure, Reichert (1981) and others found that as migrants use remittances to purchase land, they unintentionally inflate land prices, thereby making land unaffordable for nonmigrant residents (Binford 2003; Weist 1984). Land thus becomes concentrated among migrant households, and those households are likely to allow land to lie fallow or to invest in inputs that eliminate employment opportunities for local residents (Stockdale 2004). As employment opportunities evaporate, most households in high-migration communities are likely to become dependent on remittances for income and/or to migrate themselves. Goldring (1990) added that although these inflationary pressures affect the relative value of investing in land or cattle, local conditions also matter (see also Jokisch 2002; Rahman 2000; Roberts 1982). Poor-quality infrastructure and services, as well as a lack of employment opportunities, both stimulate migration and constrain local investment, such that a vicious circle emerges between underinvestment and migration. Similarly, though allowing for more variable outcomes, Lindstrom (1996) found that although migrants from stagnant areas make shorter trips with the goal of earning just enough money to support household subsistence, migrants from economically dynamic areas stay longer abroad to earn more money for local investment, because they are more likely to earn returns on their investment.

Scholarship on Southeast Asian development suggests that state policies affecting both land distribution and domestic agriculture are likely to have significant impacts on development potentials (Chibber 1999; Evans 1995; Amsden 1994; Wade 1993; Hecht et al. 2006). These scholars argue, in contrast to scholars who argue for minimal state intervention in the market, that when governments do not protect nationally produced goods from the influence of international prices (and guarantee prices for producers and/or help them to market their goods), farmers are more likely to face widely fluctuating prices for their produce, while lacking sources of credit or assistance (Acevedo, Barry, and Rosa 1995; Hecht et al. 2006; Friedman 1993). Such fluctuations are likely to jeopardize farms and local production and thus the potential for complementary relationships to form between agriculture and industry, in which productivity in one sector creates a market for goods produced in the other. As we will see in the Salvadoran case, these sorts of government policies affect how households receiving remittances invest them. In the aggregate, these investment decisions can transform communities and thus, in time, the development potential of the country as a whole.

\section{CASE SELECTION AND METHODS}

I used UNDP (2005, 2006), Salvadoran Census Bureau (Dirección General de Estadística y Censos, or DIGESTYC), and Salvadoran Program for the Investigation of Development and the Environment (Programa Salvadoreño de Investicagión sobre Desarrollo y Medio Ambiente, or PRISMA, 2005) data to identify two communities with similar populations, resources, and patterns of migration but differing preexisting land-tenure patterns: Yucuaiquín (population 8,694), which is located in the far eastern department of La Unión, and Masahuat (population 7,425), located in the far western department of Santa Ana. Residents from both 
communities began migrating to the United States in the late 1970s and continue to do so today (PRISMA 2005, 13; UNDP 2006, 128; UNDP 2005, 218, 224). Currently, an estimated 39.5 percent of Yucuaiquense households and 41.2 percent of Masahueño households receive remittances of equal value each month (PRISMA 2005; UNDP 2005, 2006); many more receive remittances on a sporadic basis. However, whereas Yucuaiquenses enjoyed relatively equitable land distribution and independent commercial farming before the onset of migration (UNDP 2006, 140), Masahuat was characterized by a high degree of land concentration and sharecropping in its premigration era. In addition, the two communities are located in similarly close proximity to large cities that are readily reachable by public and private transportation. They also have similarly well-developed communications infrastructures relative to national standards, and they enjoy similar climates and public services. Finally, most landowning households in Masahuat and Yucuaiquín own or owned between two and seven manzanas of land; averages, however, were closer to two manzanas (compared with averages of 1.14 manzanas in Van Wey's [2005] study of Mexican households, which, she argues, are sufficient to provide employment and deter migration). ${ }^{6}$

In 2006 and 2007, I spent seven consecutive months in El Salvador collecting interview and ethnographic data, and an additional month in the United States interviewing migrants from Yucuaiquín and Masahuat. Research in El Salvador yielded 102 interviews; hundreds of hours of observation and field notes; and documents reflecting social, economic, and political indicators. Research in the United States yielded an additional sixteen interviews and many more hours of observation and field notes.

In El Salvador, I interviewed sixty-three households and an additional thirtynine individuals. Households were selected via a random sampling technique in which I used maps to number households and a random number generator to select an approximate 15 percent sample. With response rates of 97.5 percent in Yucuaiquín and 96 percent in Masahuat, this sample alone yielded a total of forty households in Yucuaiquín and twenty-three in Masahuat. ${ }^{7}$ The thirty-nine additional interviews were conducted with carefully selected informants, including local leaders, youth, and elders (twenty-three in Yucuaiquín and sixteen in Masahuat). Interviews yielded extensive details on personal and community life events, as well as land use, ownership (past and present), and occupational patterns. Data from archival research and extensive daily field notes enabled me to cross-check information obtained from interviews, confirm the timing of events, compare what people say with what they do, and contextualize testimonies on the basis of what was happening at the time they were given. Most important, the ethnographic research uncovered evidence about how migration affects local change and toward what ends, as well as how preexisting conditions in each place affected the realm of possibilities for development.

The interview excerpts that appear throughout the text are representative of the experiences expressed by informants, and they were selected on the basis of

6. Ownership here implies land title. One manzana is equal to 1.68 acres.

7. Masahuat has a denser urban core, with fewer houses. 
the level of detail and clarity they provide. Descriptive statistics are derived from the randomly sampled interviews. Pseudonyms are used to protect informants' identities.

\section{EMPIRICAL PUZZLE}

Today, it appears that households in Yucuaiquín and Masahuat not only receive remittances in nearly equal proportions but also own arable land at similar rates. Whereas 28 percent of households in Yucuaiquín own arable land, the figure for Masahuat is 22 percent. This second similarity, however, obscures an important historical difference and opposing trends between the two communities: whereas Masahueños gradually acquired arable land from a handful of landowners, Yucuaiquenses have been selling it, often to absentee owners who live in the United States. Before mass migration began in earnest during the 1980s, 65 percent of households in Yucuaiquín owned arable land, whereas only 9 percent of households in Masahuat were landed. Masahueños also make greater efforts to rent land than do Yucuaiquenses: 26 versus 8 percent of households rent land to cultivate.

Landowners in each town tend to pursue commercial over subsistence agriculture. Figures 1 and 2 illustrate the relationship between residents' connection to land and how they earn a living. In Masahuat, 60 percent of those who own arable land focus on market agriculture, whereas 36 percent prioritize subsistence. In Yucuaiquín, 36 percent of landowning households farm commercially, whereas 18 percent farm exclusively for their subsistence. However, figure 3 illustrates that although more households in Masahuat prioritize farming over nonagricultural

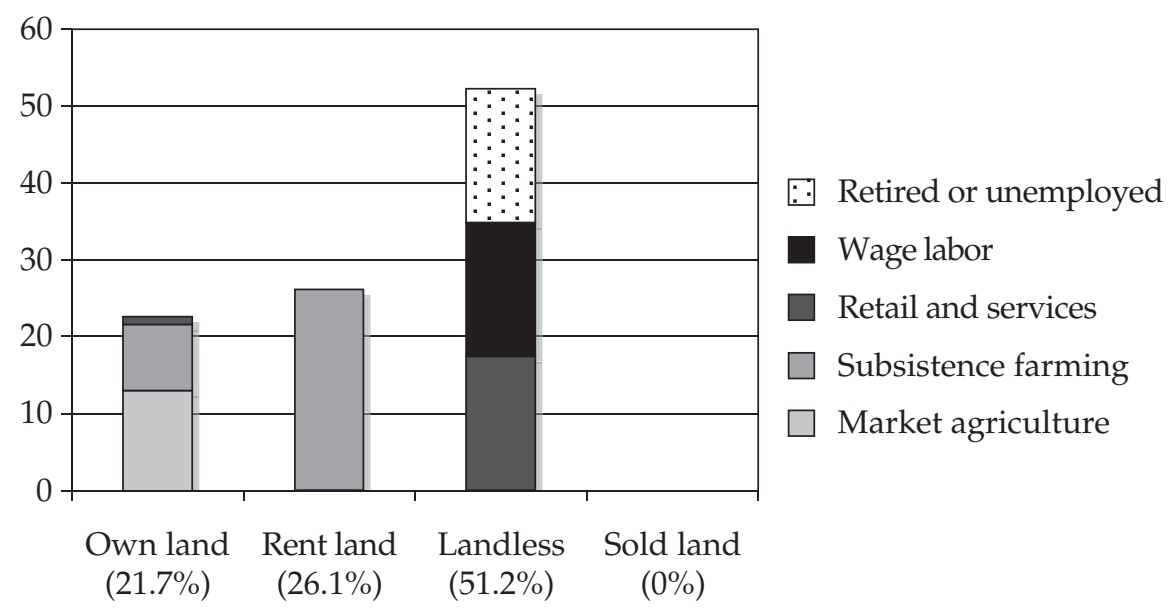

Figure 1 Occupation by land-tenure status: Primary household activity in Masahuat, 2006-2007 


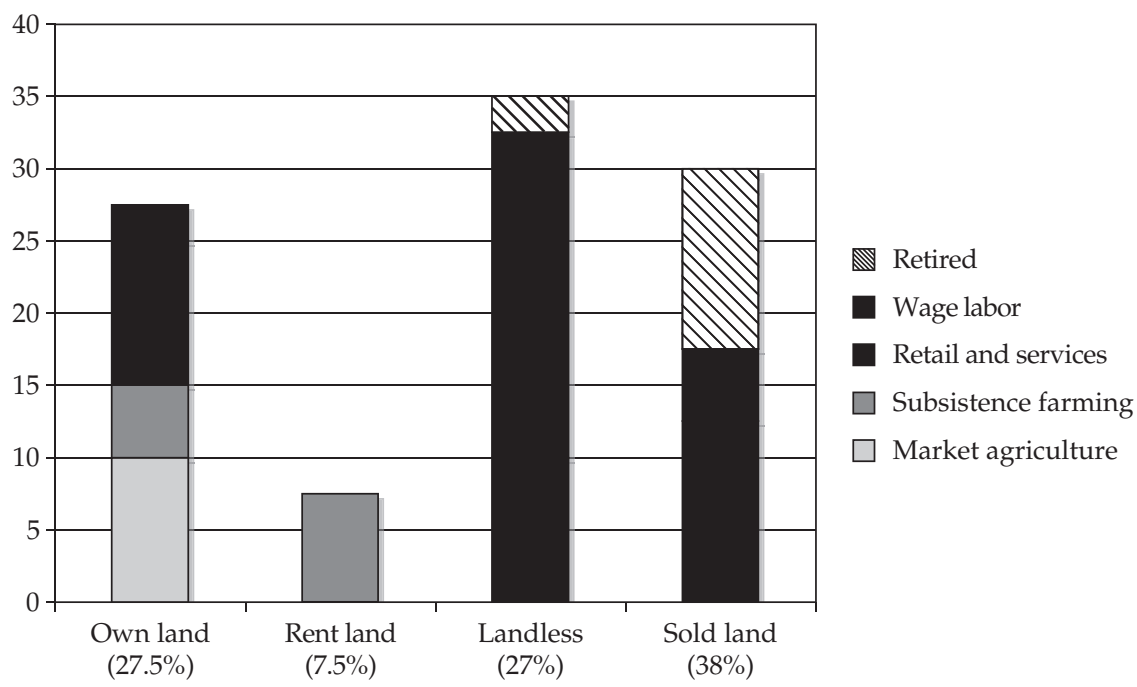

Figure 2 Occupation by land-tenure status: Primary household activity in Yucuaiquín, 2006

activities, the largest share of households in Yucuaiquín provides retail and services outside of agriculture. Slightly more than 22 percent of households in Yucuaiquín focus on agriculture, versus 43 percent of households in Masahuat. Even among landowning households in Yucuaiquín, almost half (45 percent) focus on nonagricultural activities. By contrast, in Masahuat only 4 percent of landed households engage in retail and services.

Finally, more Yucuaiquenses than Masahueños own stores or provide retail services (32 percent versus 22 percent). Nonagricultural businesses in Yucuaiquín not only outnumber those in Masahuat but also have larger inventories. Table 1 reflects the size of the retail sectors in Yucuaiquín and Masahuat. There are about four times as many large and small retail businesses in Yucuaiquín as in Masahuat, despite their similar populations. Several of the retail businesses listed in the "small business" category in both places, however, consist of a few shelves worth of personal goods sold out of humble family homes. By contrast, the large retail businesses in Yucuaiquín are based on investments of US\$6,000 (or more), and while there are a total of twenty-eight high-investment businesses in Yucuaiquín, there are none in Masahuat. ${ }^{8}$

In summary, opposite processes are at work in Yucuaiquín and Masahuat. Before the onset of migration in the late 1970s, most Yucuaiquenses owned their own land. By contrast, few Masahueños entered the migration period owning land.

8. Businesses with larger inventories in Yucuaiquín include local groceries; hardware stores; shops for clothing, shoes, and household goods (e.g., linens, small appliances, cookware); and pharmacies. 


\section{Latin American Research Review}

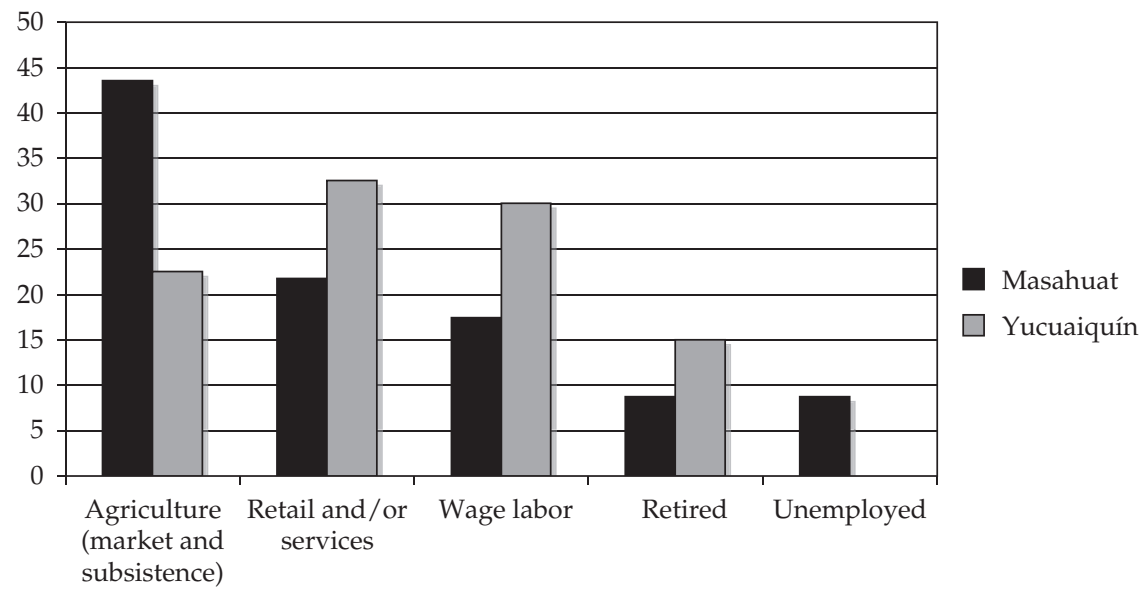

Figure 3 Percentage of randomly sampled households participating in occupation, by category, Yucuaiquín and Masahuat, 2006-2007

Table 1. Number of businesses by category, 2006-2007

\begin{tabular}{lcc}
\hline & Yucuaiquín & Masahuat \\
\hline Large businesses* $^{*}$ & 28 & 0 \\
Small businesses $^{* *}$ & 58 & 19 \\
Service & 23 & 10 \\
Industry & 3 & 1 \\
\hline
\end{tabular}

*Investments worth US $\$ 6,000$ or more

**Less than US\$6,000 invested

Through the course of migration, historical differences in land-tenure patterns have nearly been erased, and land usage itself has significantly changed. How did this happen and with what implications for development?

\section{ANALYSIS}

Land is an important form of capital in El Salvador. The civil war in El Salvador (1980-1992) was fought in large part over highly unequal land distribution patterns, in which six families owned and controlled more land than did 133,000 farmers combined (McReynolds 2002, 165; Dunkerley 1988). Such concentration was worse in some regions than in others. Whereas the eastern departments where Yucuaiquín is located have historically been characterized by more equitable distribution patterns, western departments where Masahuat is located were characterized by higher land concentration. This is because many of the coffee, 
cotton, and sugar plantations (haciendas) originated in the west and spread down the southern coast, toward but rarely reaching the east.

The majority of Masahueños thus subsisted as colonos, or sharecroppers, on Hacienda Chilín or Carrizal, squatting or borrowing small plots of land on which to build a house and make a subsistence-based living (milpa). A few local hacienda owners controlled more than 1,600 acres of land that they acquired in the nineteenth century through a combination of legal purchases and land grabs. Most Masahueños received from the hacendados a small plot of land; in exchange, they surrendered a portion of their produce and provided labor service (paid and unpaid).

Antonio (born in 1935): One lived [on the hacienda] like some child, because they put you to work like they wanted. Harvesting corn, beans, herbs, cumin, and taking care of the livestock. And if they didn't like you, well, they threw you out and you had to go . . . to other haciendas.... They [hacendados] demanded that you perform six jobs without pay. And the others they would pay-cheap. ... For the six jobs that one did in the year, that was just for the plot they loaned you where you could live. And then you had to irrigate the livestock, [but] they didn't pay you for that. That was for free-for the land on which one lived.

Yucuaiquenses, by contrast, were much more likely to own their own land. They often migrated to provide seasonal wage labor on regional haciendas and invested their earnings in production on their own lands, as well as in founding a variety of small businesses. Bus and ox owners offered transportation services to assist farmers in marketing their wares regionally, and many women opened small stores to sell farm implements, pharmaceuticals, and fresh produce.

Pablo (born in 1930): Everybody worked in the same thing. We migrated to pick cotton on cotton farms in San Salvador. People were also cutting coffee, thousands of us, to earn a wage. First it was coffee, then cotton, then sugarcane. One to two thousand people would go to work on the haciendas. We went to pick [or cut] and then on Sundays we would go sell our own goods.... People would go to mines that were over in Divisadero ... to sell fruit; bread; many things. They took things [also] to San Miguel. ... They would go on average one day [a week], to sell watermelon, melons, mango, all of that. Sometimes they would go with oxdrawn carts.... Or, trucks would come from Guatemala and Honduras to buy mango.

Salvador (born in 1956): When there were haciendas here we started to have business, it was really great! The hacienda was close by and when people went to work on it, they brought back money. They bought their lands and built their houses. ... One girl who worked with the others there-today she's in Houston-with just her earnings from picking cotton, she bought land and built a house. People did it!

Pablo and Salvador, like the majority of Yucuaiquenses in the 1970s, inherited both land and small businesses that their parents had acquired in a relatively diversified local economy. In the 1980s, however, a division within the ruling class in El Salvador augured in an era of trade liberalization in which agro-industrialists promoted modest land reform; a partial democratic transition; and implementation of foreign-owned and foreign-operated assembly plants, or maquilas (Paige 1997). These changes came at the expense of domestic agriculture (Hecht et al. 2006). Declining returns on investments in agriculture encouraged many Yucuaiquenses to begin selling their lands. In so doing, they raised capital to launch or 


\section{Latin American Research Review}

expand small retail businesses that were increasingly patronized by other local residents receiving remittances. Crucially, owning arable land provided Yucuaiquenses with the resources necessary to diversify their economic activities and cope with massive social change: arable land was an important form of capital.

The national restructuring of El Salvador's economy had a different effect on Masahueños: for the first time, a majority of local residents acquired rights to purchase land. Unfortunately, Masahueños' efforts to raise money and buy land did not go unchallenged by the former hacendados, who devised new ways of excluding residents from becoming landowners and independent farmers. However, the hacendados' efforts were only partially successful:

Antonio (born in 1935): Certain governments discovered a law, the ISTA, ${ }^{9}$ which said that the land had to be leased-without obligations, but rather leased or sold. And from that time on people started to work differently. ... So the owners invented ways to throw us off the lands and use them for livestock. They said it was better to have livestock than people.... [Colonel Arturo Armando Molina's] government, though, it fought for the poor. And that was how progress was made in this town, for the poor. Some of us bought a place to live, [and] a means of working, finally our own. For example, I bought twenty-five manzanas [forty-two acres]. . . . The time was ripe for everything, right? So you had to take advantage. To have your little house. To have your own things. We stopped being servants to the owners. [To buy the land] sometimes they allowed you to pay each year. ... If you want one manzana, two manzanas. Maybe you pay two and they give you one to work on to pay them. You would make your own harvest. From that you would pay.... You [no longer had] to surrender it to the boss. You just bought your land and that was that.

Because agriculture had been profitable through the late 1970s, Masahueños dedicated their resources to purchasing or renting land. They believed that their prospects in farming were excellent.

\section{Migration Era}

Yucuaiquenses and Masahueños entered the migration era, which began with the onset of war, in different positions that would significantly affect how residents subsequently coped with social change. Using land as capital, Yucuaiquenses shifted their energies away from agriculture and toward retail. This was fortunate, as liberalized trade with the United States, elimination of subsidies for domestic farmers, and the recent dollarization of the national economy have adversely affected farmers. Masahueños, by contrast, were still in the process of acquiring land and were thus unable to use land as a form of capital to launch a retail sector when agriculture began to fail. The result in Masahuat is that increasing numbers of families are relying on subsistence farming to offset their costs of living, whereas Yucuaiquenses are giving up on agriculture and hoping to make a living by selling retail goods locally.

9. ISTA is the Instituto Salvadoreño de Transformación Agraria, or Salvadoran Institute for Agrarian Transformation. Founded in the late 1970s, its mission was to transfer lands affected by agrarian reform laws to designated rural families (Barraclough and Scott 1988). 


\section{Yucuaiquín}

El Salvador's violent civil war made it dangerous for farmers to cultivate their land and resulted in agro-industrialists wresting power from the agrarians and raising the costs of farming (Paige 1997; Hecht et al. 2006). War-induced migration also depleted local labor forces and, when remittances began arriving in the 1980s, encouraged remaining workers to demand higher wages. Farmers could thus use more herbicides and pesticides to compensate for weeding that would otherwise be done by hand, as well as more fertilizer when the quality of the soil consequently deteriorated; limit their farming to subsistence over commercial agriculture to reduce the cost of inputs; and/or quit farming altogether. The few who persisted struggled. In one former farmer's words:

Martín (born in 1974): If you invest, let's say, in one manzana, or seven square meters of land, you invest about 500 dollars. You won't get the 500 back. You might get 475 . Or, only what is your subsistence. Why? Because . . . the prices of fertilizer have risen. . . . So it's not profitable. Why? Because agriculture is profitable when it's subsidized. Here there is nothing. So, it doesn't work. ... The emigration also has affected [the rise in agricultural wages] because before agricultural workers, they used to charge twenty-five colones. Now, with emigration, they all got together and agreed that "we're going to charge four dollars" [per day]. That's thirty-five colones. Then they raised it to six [dollars] [forty-eight colones]. So, it seems migration has affected quite a bit.

However, migration also created a buyers' market for land in Yucuaiquín. Migrants in the United States who earned wages in dollars realized that they had substantial spending power in El Salvador: before 2001, \$1 translated into 8.75 colones, and prices were set according to the colón. Wishing to build retirement homes or better homes for their relatives, migrants began snapping up land. In the process, they inflated land prices, further increasing the incentives for local farmers to sell.

Maritza (born in 1970): Those that buy land are those who have left for there [the United States]. Because those of us who live here can't buy. We don't have the money to be able to buy. ... It's that there [in the United States], there's work, and they earn on an hourly basis, too. And so there, they set the price.

Author: What do the buyers do with the land?

Maritza: They buy it, they build on it, they fix it up, and maybe give it to their relatives.

Author: How much does land cost?

Martín: Land prices are approximately between twenty and twenty-two dollars per square meter. Yeah, and before it was at about four or five dollars. Now, here's the thing-emigration also came to affect this. Because [buyers] have money from remittances and they pay well. . . . So poor people can't pay as much. Lands were cheap. But later a great increase occurred, perhaps 200 percent.

Author: In how many years?

Martín: In terms of fifteen years. .. . It rose too much. ... Here land is expensive because of emigration, or people who have gone [emigrated] bought land, right? A common house in 1986 cost about 1,500 dollars. Now it's close to 35,000 dollars. 35,000 dollars! Sometimes people ask 50,000 dollars.

With the money Yucuaiquenses earned by selling land, they bought inventory for small stores, which they opened in the heart of town. Others used land as col- 


\section{Latin American Research Review}

lateral for loans from banks in San Miguel. Mateo (born in 1978) was among those who lacked land but wanted to raise capital to open Yucuaiquín's only auto-repair shop. He argued that landowners can apply for low-interest loans using land as collateral, whereas the landless often have to borrow from local residents charging high interest rates:

Mateo: If a person requests a loan, the first thing [the bank officials] ask for is a pay stub. And if your salary is really low, they won't loan you the money. Because the banks are under regulation not to loan. If you go to look for money with another person, they'll charge you a high interest. There are people who charge 10 percent each month ... They're men and women who have kids there [in the United States] who send [remittances] to them. There are people here who have made money that way.

Yucuaiquenses' historical access to land as a form of capital enabled them to foster their retail sector in yet another significant manner: by acquiring US travel visas and launching courier (viajero) services that provide a steady and direct stream of remittances to Yucuaiquín. Having owned land in the past, Yucuaiquenses were better able to acquire travel visas to the United States, which their landless counterparts in and near Masahuat were unable to do. Local viajeros ensure the continuous safe delivery of migrant remittances to Yucuaiquín, as well as local cash flow that can benefit local proprietors (Garni n.d.).

Unfortunately, the dollarization of the national economy in 2001 has hurt Yucuaiquenses' retail sector. Dollarization reduced the local purchasing power of remittances: \$200 of migrant remittances no longer bought several times their value in goods. This discouraged migrants' further land acquisition, halted home construction and remodeling, and reduced how much those receiving remittances could spend locally. The result is a sluggish retail sector that is increasingly tied to the US economy.

Maritza: [The] problem is that in Yucuaiquín, the economy is really low, ever since there was the attack on the twin towers in the United States. ... And then, just as it was recovering again Katrina ... and Stan [the hurricanes] hit... . And that affected us ... because the price of oil rose. And as everything runs on oil, now a pound of beans that arrives in Yucuaiquín, it's by way of oil. And when it's expensive, their prices rise. So the economy in Yucuaiquín is bad. Even when the ... viajeros . . . bring money from the United States - they used to bring 200 dollars to one family, now they bring no more than 100 dollars. . . And now people don't sell the same. ... They're earning less. ... When people don't have money from the United States, the stores are empty.

Ana (born in 1971): Now we farm very little because ... now you can't sell like you could before. Today we get our goods from San Miguel. And before there wasn't business that came from San Miguel to here. You see, we used to sell what we produced. And in those days we sold a lot better. Now we have to bring things in from there [San Miguel] and people buy fewer things that come from here.

This is a significant contrast with the past, when stores were stocked with locally produced goods (eliminating transport costs) and additional jobs were available on local and regional farms that have since disbanded. The decline of agriculture in Yucuaiquín with national restructuring and migration has virtually eliminated the symbiosis between farming and retail that Yucuaiquenses had previously enjoyed. So although at first Yucuaiquín may seem like a development 
success story, a closer examination of the historical trajectory and current context reveals a darker picture and problems ahead.

\section{Masahuat}

Unlike Yucuaiquenses, landowners in Masahuat are hesitant to relinquish their landholdings. Those Masahueños who managed to buy land in the late 1970s and early 1980s continue to farm it and rent portions to those who, as yet, have been unable to buy land. Remaining Masahueños use their remittances to pay rent and buy fertilizer and herbicides. They do this, they argue, because they have no other choice. Lacking the assets in land, which Yucuaiquenses had at the outset of migration, Masahueños have been unable to develop a viable retail sector.

Renting land for approximately $\$ 150$ per manzana per season, landowners are ensured an income, even if the renters' crops fail, as they often do. Renters, in contrast, figure that even if they cannot produce enough to profit from farming, they can reduce their costs of living by raising their own food. They are rarely able to purchase land because of the subsistence nature of their farming, and because rental agreements limit them to raising crops such as sorghum and corn that fetch lower prices than many fruits would. (Fruit trees take years to mature, and rental agreements are seasonal. Any trees that tenants plant become the property of the landowners, and landowners prefer that tenants raise grains because they can graze their cattle on the shorn grain stalks that remain after each harvest.) As a result, despite receiving remittances, many Masahueños struggle to eke out a living farming:

Author: A local farmer told me yesterday that he invested \$3,500 [mostly remittances] last year and wound up losing $\$ 500$ in the end.

Alejandra (born in 1969): That's true because my brother cultivated about three years ago, ... [but] he didn't get back even half of what he invested. ... He lost instead of earning. Mauricio (born in 1928): Agriculture is through the floor. I mean to say, trashed. If you use fertilizer, your crop will grow but you won't break even. The price is worthless. Look, I'm going to speak about one manzana of land. People invest 3,000 colones [approximately $\$ 345]$ to harvest twenty-five loads, which make up an arroba. To sell here, with the dollar, we're losing 500 colones [\$57] for every manzana.

Antonio: For the farmer, things are terrible. ... One works with compromise [debt]. That's to say that you give me fertilizer on credit, pesticides on credit. When the harvest is ready I have to pay you back. And these days everything [is selling] so cheap. Fifteen dollars for a hundred pounds of corn-you can't sell. You won't have enough for a sack of pesticides, fertilizer. ... Maybe you'll produce enough to eat for the year. To dress yourself, perhaps not.... One works because he has to have something to do, but it's going for broke. . . We don't have anything else.... One has to, by force, ... work in agriculture.

Rising local land prices are less of an issue for Masahueños than for Yucuaiquenses, but only because there is virtually no land for sale. Most farmers in Masahuat in fact rent in a manner similar to what they did in the past when the haciendas existed: renters pay landowners cash to rent parcels of land and must leave the remains of their harvests for the landowners to graze their cattle on before they rent the parcels again in the next season. Profiting thus, owners are rarely interested in selling their lands. In one recent instance in which an owner 


\section{Latin American Research Review}

did agree to sell, a migrant in the United States bought the land, divided it into parcels, and then marketed small parcels to others wishing to build homes, not to farm. This is what has occurred in Yucuaiquín, although in Masahuat it is the exception rather than the rule.

Unlike Yucuaiquenses, Masahueños in general have been unable to develop small businesses to diversify sources of income. This is for three primary reasons. First, Masahueños lacked resources in land that would have provided them with the capital or collateral necessary to launch businesses. Second, there are no banks in Masahuat, nor any viajeros bringing money into town (also related to the historical lack of land ownership). Thus, whereas Yucuaiquenses receive remittances securely at their doorsteps and spend money locally, Masahueños have to travel to a nearby city, most often via public bus. This is a risky journey, and many are robbed in the process. To minimize risk, many Masahueños spend their remittances as soon as they withdraw them from city banks, figuring that assailants are less likely to steal groceries than cash. Few Masahueños retain the money to patronize the limited number of businesses that exist in Masahuat. Because the few existing small-business owners in Masahuat are consequently unable to expand their inventories, potential customers are more likely to seek variety and discount in the city, thereby creating a further obstacle to local business growth (Garni n.d.). Finally, because commercial agriculture has not taken off in Masahuat, few people have locally generated income to spend.

One family that has long owned land in Masahuat has managed to run a variety of nonagricultural businesses, precisely because the family owned land to start. When agriculture began its descent, the family transitioned into raising livestock. When that became less profitable in the 1990s, the family sold their cattle and bought a bus, van, and several computers (without selling their land). They now strategically own the only Internet café in town. However, because few Masahueños spend cash locally, Óscar (born in 1972) and his wife, Carmen (born in 1975), make most of their money running the bus six days a week. Óscar explains that having land enabled him to diversify his investments.

Óscar: The financial system is really hard on the question of loans. And practically everything has to be done through a mortgage. If it's not for agriculture, if it's for another kind of business of, let's say vehicles, or anything that is not directly related to agriculture, you always have to leave a mortgage [collateral]. It's always by way of a mortgage.

Long-standing landowners thus have a significant advantage over landless or land-poor households; but in Masahuat, this is the exception.

\section{DISCUSSION}

Asking how preexisting land-tenure patterns affect development possibilities with migration enables us to understand why Yucuaiquenses were able to develop a retail sector when Masahueños were unable to do so. Land was an important form of capital for Yucuaiquenses that Masahueños lacked upon entering the migration period. However, under conditions of mass migration and unfavorable agricultural policies, Yucuaiquenses were unable to maintain their previously bal- 
anced economy, in which they invested both in agriculture and in small-business development in a mutually complementary fashion. Masahueños were unable to acquire land quickly enough to stimulate their local economy before changing domestic agricultural policies landed farmers in debt.

As many development scholars argue, mutually complementary relationships between agriculture and industry are crucial for development (Pelupessy 2000; Kay 2002; Thiesenhusen 1995; Kay 2002, 2006; Amsden 1979, 1990; World Bank 2007). The Salvadoran state's failure to promote such relationships undermines efforts to stimulate local economies. Counterfactual evidence from Yucuaiquín and Masahuat suggests that under different conditions, residents of both communities might have further developed their agricultural sectors as a foundation for diversifying their economies into industry. At the outset of migration, Yucuaiquenses were well positioned to do just that: they already owned land and small businesses at high rates. Masahueños received a historic opportunity to buy arable land, and they were eager to become independent farmers. Had domestic agriculture been more profitable, residents of both communities might have used remittances to develop both farm and off-farm activities. Instead, damaging neoliberal policies since the 1990s have prompted Yucuaiquenses to sell land and use remittances to develop retail outlets and Masahueños to rely on subsistence farming. In the hypothetical absence of migration, Yucuaiquenses would likely have retained their lands and farmed for their subsistence. Masahueños would have lacked the land and remittances that have enabled them to withstand poor national conditions for farming. Masahueños would thus likely be in a particularly desperate situation.

In contrast to findings that remittances are primarily responsible for stimulating small-business development because they enable households to overcome local market or capital constraints (Taylor 1992, 2006; Taylor et al. 1996; Durand, Parrado, and Massey 1996; Woodruff and Zenteno 2006; Massey and Parrado 1994, 1998; Adelman, Taylor, and Vogel 1988), evidence from Yucuaiquín and Masahuat suggests that remittances alone are insufficient to enable households to launch retail businesses. In Yucuaiquín, households were able to open several businesses with relatively large inventories because they could either use land as collateral for loans from regional banks or as capital by selling it to absentee migrant landowners. Although they receive remittances at similar rates and in similar quantities, Masahueños have been unable to launch a retail sector. There are far fewer businesses in Masahuat than in Yucuaiquín, and the inventories of businesses that do exist are so limited that most local residents travel to the nearby city of Metapán to shop.

Having land at the outset of migration also enabled Yucuaiquenses to acquire US travel visas at a much greater rate than Masahueños. With access to the visas, Yucuaiquenses launched courier services between the United States and Yucuaiquín. Because Yucuaiquenses are thus able to securely receive remittances at their doorsteps, they are more likely than Masahueños to spend them locally. Masahueños, lacking any such courier services, must travel to Metapán to retrieve remittances from banks (there are no banks in Yucuaiquín or Masahuat, although couriers serve as de facto local banks for Yucuaiquenses). Rampant theft and so- 
cial violence compel Masahueños to buy groceries and other goods in Metapán because they believe that assailants are less likely to steal groceries than cash. These circumstances severely constrain the potential for developing small businesses in Masahuat. If Yucuaiquenses were forced to travel to San Miguel to retrieve their remittances, they would face similar conditions, as such violence and theft is common across much of El Salvador. However, Yucuaiquenses' high rates of land ownership in the premigration era enabled them to create an alternative to relying on city services to meet their needs; instead, they leveraged land as a form of capital to generate a courier and services industry in addition to their new retail sector, which is sustained by inflows of migrant remittances (Garni n.d.).

\section{CONCLUSION}

With the explosion and growth of migration from El Salvador, communities with different historical land-tenure patterns devised radically different development strategies that raise important theoretical questions. In the first case, in which most families owned and farmed their own lands, equity in land distribution under favorable state agricultural policies did stimulate investment in both agricultural and nonagricultural ventures during the premigration period. Subsequently, however, when state policy dampened the profitability of smallscale domestic farming, migration and remittances had the effect of encouraging households to abandon agriculture. The more difficult farming became, the more that residents who historically owned their own land sold it to engage in retail and service-based commerce. This transition has been fraught with difficulty, however, as local commerce now depends on income earned in the United States and remitted to El Salvador. Fluctuations in the US economy thus have a far greater impact on local income than they previously did. However, contra dependency theory, this outcome was highly contingent on state planning, which itself was the outcome of class struggle in El Salvador (Paige 1997; Garni and Weyher forthcoming). Thus, it was not a forgone conclusion that households in a high-migration community would abandon agriculture through the course of migration. By the same token, and contra modernization theory, investment in retail and service was insufficient to stimulate local development, as such investment occurred as a substitute for, and not a complement to, local agriculture. Finally, those scholars arguing that equity in land distribution is most likely to stimulate investment in agriculture and industry likewise may not have anticipated the effects of migration on land tenure and thus development. Had residents of this community not migrated, they would have had little choice but to persist in agriculture, despite its unprofitability. Migration thus made a significant difference in the strategies that households in this case could pursue. Rather than simply farming for their subsistence, as they might have been forced to do in the absence of migration, they instead used land and remittances to transition into retail and service.

In the case where few households owned land before migration, the timing of both the war and migration made a significant difference for what happened subsequently. Had more families been able to acquire land before migration accelerated and state policy damaged domestic farming, more households might also 
have used this land as capital and collateral to launch retail and service ventures, as in the first case. Instead, having enabled some households to acquire land, remittances now simply enable households to sustain their subsistence farming and survive crises in agriculture. Without these remittances, this community would likely be suffering far more than it is today. By contrast, according to studies suggesting that equity in land distribution promotes development, if state policy made small-scale farming profitable, households in this community could invest more broadly in agriculture and reap profits that could be invested both in agriculture and nonagricultural ventures. This outcome would challenge both modernization and dependency-based studies on migration and development, as migration would break land concentration (contra modernization) and lead to greater local investments, productivity, and development (contra dependency).

Evidence from this comparative case study suggests that equity in land distribution has significant potential to stimulate development, but migration can either interfere with or enhance this potential, depending on the relative profitability of small-scale domestic farming. If the Salvadoran state were to provide credit and assistance to farmers, guarantee domestic prices for local produce, and protect farmers from the vagaries of the international market (as the United States and many European governments have historically done), more households in high-migration communities would be more likely to invest remittances in stimulating agriculture and expanding into complementary industries. Such a scenario would likely provide a powerful basis for both local and national development.

\section{REFERENCES}

Acevedo, Carlos, Deborah Barry, and Hermán Rosa

1995 "El Salvador's Agricultural Sector: Macroeconomic Policy, Agrarian Change and the Environment." World Development 23 (12): 2153-2172.

Adelman, Irma, J. Edward Taylor, and Stephen Vogel

1988 "Life in a Mexican Village: A SAM perspective." Journal of Development Studies 25 (1): 5-24.

Alejandre Arroyo, Jesús, Adrián de León Arias, and Basilia Valenzuela Varela

1990 "Patterns of Migration and Regional Development in the State of Jalisco, Mexico." Working Paper No. 42, Commission for the Study of International Migration and Cooperative Economic Development, Washington, DC.

Amsden, Alice H.

1979 "Taiwan's Economic History: A Case of Etatisme and a Challenge to Dependency Theory." Modern China 5 (3): 341-379.

1990 “Third World Industrialization: 'Global Fordism' or a New Model?" New Left Review 182:3-31.

1994 "Why Isn't the Whole World Experimenting with the East Asian Model to Develop? Review of The East Asian Miracle." World Development 22 (4): 627-633.

2001 The Rise of "The Rest": Challenges from the West to Late Industrializing Economies. Oxford: Oxford University Press.

Andrade-Eekhoff, Catherine

2003 Mitos y realidades: El impacto económico de la migración en hogares rurales. San Salvador: Facultad Latinoamericana de Ciencias Sociales and Impresos Quijano.

Barraclough, Solon L., and Michael F. Scott

1988 "The Rich Have Already Eaten: Roots of Catastrophe in Central America." Working Paper No. 105, Kellogg Institute for International Studies, University of Notre Dame, Notre Dame, IN. http://kellogg.nd.edu/publications/workingpapers/WPS/ 105.pdf. 


\section{Latin American Research Review}

Binford, Leigh

2003 "Migrant Remittances and (Under)Development in Mexico." Critique of Anthropol-

Block, Fred ogy 23 (3): 305-336.

1990 Postindustrial Possibilities: A Critique of Economic Discourse. Berkeley: University of California Press.

Bulmer-Thomas, Victor

1987 The Political Economy of Central America since 1920. Cambridge: Cambridge University Press.

Chibber, Vivek

1999 "Building a Developmental State: The Korean Case Reconsidered." Politics and Society 27 (3): 309-346.

Conning, Jonathan, Pedro Olinto, and Alvaro Trigueros

2001 "Managing Economic Insecurity in Rural El Salvador: The Role of Asset Ownership and Labor Market Adjustments." Working Paper 2001-09, Department of Economics, Williams College, Williamstown, MA. http://www.williams.edu/Economics/ wp/conningsalvador.pdf.

de Janvry, Alain

1981 The Agrarian Question and Reformism in Latin America. Baltimore, MD: Johns Hopkins Press.

Dirección General de Estadística y Censos/Census Bureau of El Salvador

2012 Población y estadísticas demográficas. http://www.digestyc.gob.sv/.

Dunkerley, James

1988 Power in the Isthmus: A Political History of Modern Central America. London: Verso.

Durand, Jorge, and Douglas S. Massey

1992 "Mexican Migration to the United States: A Critical Review." Latin American Research Review 27 (2): 3-42.

Durand, Jorge, Emilio A. Parrado, and Douglas S. Massey

1996 "Migradollars and Development: A Reconsideration of the Mexican Case." International Migration Review 30 (2): 423-444.

Evans, Peter B.

1995 Embedded Autonomy: States and Industrial Transformation. Princeton, NJ: Princeton University Press.

Findley, Sally E.

1987 "An Interactive Contextual Model of Migration in Ilocos Norte, the Philippines." Demography 24 (2): 163-190.

Friedmann, Harriet

1993 "The Political Economy of Food: A Global Crisis." New Left Review 197:29-57.

Gammage, Sarah

2006 "Exporting People and Recruiting Remittances: A Development Strategy for El Salvador?" Latin American Perspectives 33 (6): 75-100.

Garip, Filiz

2010 "The Impact of Migration and Remittances on Wealth Accumulation and Distribution in Rural Thailand." Working Paper No. 2010-0010, Weatherhead Center for International Affairs, Harvard University, Cambridge, MA. http://www.wcfia

Garni, Alisa .harvard.edu/node/5996.

n.d. "Viajeros in the Salvadoran Migration Industry: A Local Comparative Perspective." Unpublished manuscript.

Garni, Alisa, and L. Frank Weyher

Forthcoming "Dollars, 'Free Trade,' and Migration: The Combined Forces of Alienation in Postwar El Salvador." Latin American Perspectives.

Goldring, Luin

1990 "Development and Migration: A Comparative Analysis." Working Paper No. 37, Commission for the Study of International Migration and Cooperative Economic Development, Washington, DC.

Haas, Hein de

2010 "Migration and Development: A Theoretical Perspective." International Migration Review 44 (1): 227-264. 
Hausmann, Ricardo, and Dani Rodrik

2005 "Self-Discovery in a Development Strategy for El Salvador." Economía (Fall): 43-87.

Hecht, Susanna B., Susan Kandel, Ileana Gomes, Nelson Cuellar, and Hermán Rosa

2006 "Globalization, Forest Resurgence, and Environmental Politics in El Salvador." World Development 34 (2): 308-323.

Jokisch, Brad D.

2002 "Migration and Agricultural Change: The Case of Smallholder Agriculture in Highland Ecuador." Human Ecology 30 (4): 523-550.

Kay, Cristóbal

1995 "Rural Latin America: Exclusionary and Uneven Agricultural Development." In Capital, Power, and Inequality in Latin America, edited by Sandor Halebsky and Richard L. Harris, 21-51. Boulder, CO: Westview Press.

2002 "Why East Asia Overtook Latin America: Agrarian Reform, Industrialisation and Development." Third World Quarterly 23 (6): 1073-1102.

2006 "Rural Poverty and Development Strategies in Latin America." Journal of Agrarian Change 6 (4): 455-508.

Kearney, Michael

1986 "From the Invisible Hand to Visible Feet: Anthropological Studies of Migration and Development." Annual Review of Anthropology 15:331-361.

Lardé y Larín, Jorge

2000 El Salvador: Historia de sus pueblos, villas y ciudades, 2nd ed. San Salvador: Consejo Nacional para la Cultura y el Arte.

Levitt, Peggy, and Ninna Nyberg-Sørensen

2004 "The Transnational Turn in Migration Studies." Global Commission on International Migration, Global Migration Perspectives No. 6, Geneva.

Lindstrom, David P.

1996 "Economic Opportunity in Mexico and Return Migration from the United States." Demography 33 (3): 357-374.

Massey, Douglas S.

1988 "Economic Development and International Migration in Comparative Perspective." Population and Development Review 14 (3): 383-413.

Massey, Douglas S., Rafael Alarcón, Humberto González, and Jorge Durand

1987 Return to Aztlán: The Social Process of International Migration from Western Mexico. Berkeley: University of California Press.

Massey, Douglas S., and Emilio A. Parrado

1994 "Migradollars: The Remittances and Savings of Mexican Migrants to the United States." Population Research and Policy Review 13:3-30.

1998 "International Migration and Business Formation in Mexico." Social Science Quarterly 79 (1): 2-20.

McReynolds, Samuel A.

2002 "Land Reform in El Salvador and the Chapultepec Peace Accord." Journal of Peasant Studies 30 (1): 135-169.

Paige, Jeffery M.

1997 Coffee and Power: Revolution and the Rise of Democracy in Central America. Cambridge, MA: Harvard University Press.

Pelupessy, Wim

2000 "Institutional Constraints and Internal Dynamics of Land Reform in El Salvador and Taiwan." In Agrarian Policies in Central America, edited by Wim Pelupessy and Ruerd Ruben, 1-16. New York: St. Martin's Press.

Programa Salvadoreño de Investigación sobre Desarrollo y Medio Ambiente

2005 "Dinámica migratoria, medios de vida rurales y manejo de recursos naturales en El Salvador" ["The Migratory Dynamic, Modes of Rural Life and Natural Resource Use in El Salvador"]. http://www.prisma.org.sv/index.php?id=44.

Rahman, Mizanur

2000 "Emigration and Development: The Case of a Bangladeshi Village." International Migration 38 (4): 109-130.

Reichert, Joshua S.

1981 "The Migrant Syndrome: Seasonal U.S. Wage Labor and Rural Development in Central Mexico." Human Organization 40 (1): 46-56. 


\section{Latin American Research Review}

Ripton, John

2006 "Export Agriculture and Agrarian Crisis: Salvadoran Peasants and the Global Market." Latin American Perspectives 33 (6): 101-135.

Roberts, Kenneth D.

1982 "Agrarian Structure and Labor Mobility in Rural Mexico." Population and Development Review 8 (2): 299-322.

Sana, Mariano, and Douglas S. Massey

2005 "Household Composition, Family Migration, and Community Context: Migrant Remittances in Four Countries." Social Science Quarterly 86 (2): 509-528.

Stockdale, Aileen

2004 "Rural Out-Migration: Community Consequences and Individual Migrant Experiences." Sociologia Ruralis 44 (2): 167-194.

Taylor, J. Edward

1992 "Remittances and Inequality Reconsidered: Direct, Indirect, and Intertemporal Effects." Journal of Policy Modeling 14 (2): 187-208.

2006 "International Migration and Economic Development." Paper prepared for the International Symposium on International Migration and Development, Population Division, Department of Economic and Social Affairs, UN Secretariat, Turin, Italy, June 28-30.

Taylor, J. Edward, Joaquín Arango, Graeme Hugo, Ali Kouaouci, Douglas S. Massey, and

Adela Pellegrino

1996 “International Migration and Community Development." Population Index 62 (3): 397-418.

Taylor, Matthew J., Michelle J. Moran-Taylor, and Debra R. Ruiz

2006 "Land, Ethnic, and Gender Change: Transnational Migration and Its Effects on Guatemalan Lives and Landscapes." Geoforum 37 (1): 41-61.

Thiesenhusen, William C.

1995 "Land Reform Lives!" European Journal of Development Research 7 (1): 192-209.

Thomas, Brinley

1966 "From the Other Side: A European View." Annals of the American Academy of Political and Social Science 367:63-72.

UNDP (UN Development Program)

2006 Indicadores municipales sobre desarrollo humano y objetivos de desarrollo del milenio, El Salvador 2005. San Salvador: UN Development Program.

2005 "Informe sobre desarrollo humano, El Salvador 2005: Una mirada al nuevo nosotros/El impacto de las migraciones" ["Report on Human Development in El Salvador: A Look at the New Us/The Impact of Migration"']. San Salvador: UN Development Program.

USCIS (US Citizenship and Immigration Services)

2009 "Immigrant Enforcement Actions: 2008." http://www.dhs.gov/ximgtn/statistics/ publications/yearbook.shtm.

Van Wey, Leah K.

2005 "Land Ownership as a Determinant of International and Internal Migration in Mexico and Internal Migration in Thailand." International Migration Review 39 (1): 141-172.

Wade, Robert

1993 "The Visible Hand: The State and East Asia's Economic Growth." Current History 92:431-440.

Weist, Raymond

1984 "External Dependency and the Perpetuation of Temporary Migration to the United States." In Patterns of Undocumented Migration, edited by Richard C. Jones, 110-135. Totowa, NJ: Rowman and Allanheld.

Woodruff, Christopher, and Rene Zenteno

2006 "Migration Networks and Microenterprises in Mexico." Journal of Development Economics 82 (2): 509-528.

World Bank

2007 World Development Report 2008: Agriculture for Development. http://web.worldbank .org/WBSITE/EXTERNAL/EXTDEC/EXTRESEARCH/EXTWDRS/0,,contentMD K:23062293 pagePK:478093 piPK:477627 theSitePK:477624,00.html. 